by $H$. Borsook. In the present article I have tried to bring into prominence a feature of co-enzymatic reactions, which has not, so far as I know, been noticed until now. It is the role of polyenzymatic co-enzymes in bringing electrons, atoms or groups into one collector, and distributing them further in an exergonic way, to organic acceptors, in fermentations and in the anaerobic part of aerobiosis, or to fixed coenzymes of the pathway of oxidation, in the aerobic part. They are a part of the catalytic apparatus of organisms which contribute to such a co-operation of specific enzymes by which these enzymes, without losing their specificity in the primary reactions they catalyse, are able to perform each more than one transformation of the metabolites.

\footnotetext{
1 For a more comprehensive review, see Parnas, J. K., Glykogenolyse, Hdb. d. Enzymologie (Nord u. Weidenhagen, 2, 902-967, Leipzig 1940 , or Ouspechi Sovrem. Biologii, U.S.S.R., 12,393, 1940), also the article by W. Franke in the same volume. Also: D. E. Green, "The Mechanisms of Biological Oxidations", London, 1941 .

2 Synonymous with what is called by different authors 'co-enzyme I' and 'co-enzyme II', or 'codehydrase I and codehydrase II', or 'pyridine' or 'pyridine-nucleotide'. Cozymase was discovered by Harden and Young, given this name, and investigated, under the same, in numerous papers by von Euler and Myrbäck. There is no reason for giving a substance a new trivial name after the isolation and elucidation of its structure. Phospho-cozymase is a logical extension of the name cozymase for its derivative containing one phosphate group more.
}

\section{BOTANY IN INDIA}

\section{By SIR GEOFFREY EVANS, C.I.E.}

A T the thirtieth Indian Science Congress held in Calcutta early this year, the Section of Botany was presided over by Dr. Kalipada Biswas, director of the Royal Botanic Garden, Calcutta. In his presidential address, which is entitled "Systematic and Taxonomic Studies on the Flora of India and Burma", Biswas dealt very fully with many aspects and covered such a wide range of subjects that it is obviously impossible, in the limited space available, to attempt more than a general summary.

In the opening stages of his address, an account is given of the history of systematic and taxonomic researches in India. The investigations, on lines followed by Western countries, can be divided into three main periods. The first period was from 1768 until 1848 and started with the pioneer work of Koenig, who was the first to introduce the Linnean system into India. Great encouragement to the work was caused by the foundation of the Royal Botanic Garden at Sibpur, Calcutta, in 1787, by Colonel Robert Kyd, who was honorary superintendent of what was then the East India Company's Garden, and it was after Roxburgh had succeeded Kyd on the latter's death that botanical researches on a proper basis may be said to have become properly established in India. The manuseripts of "Flora Indica" and "Hortus Bengalensis" were completed by him between 1794 and 1813, and he was rightly known as the Father of Indian Botany.

The second period begins about 1846 with the first visit of Sir Joseph Hooker. This was a great period for botanical exploration and collection, and is full of the names of many famous botanists who made valuable contributions to both systematics and the enhancement of the plant collections in the Sibpur Herbarium, and also to the interchange of specimens with Kew and other famous herbaria.
Full tribute is paid to the long list of illustrious names of famous botanists who have in turn ruled over the destinies of the Royal Botanic Garden in Calcutta and done so much to foster botanical research. Biswas points out how, until quite recently, nearly all the original work has been carried out by Europeans and that only about 30 per cent of work published has been contributed by Indians. He asserts that very few members of the staff of Indian universities take any interest in systematic and taxonomic studies, preferring to devote their attention to those other branches of botanical research that can be carried out in laboratories, rather than the undertaking of prolonged field work and subsequent determinations of the plants collected. One of the results is that Indian workers on systematics are now mainly confined to Government institutions in Calcutta or at Dehra Dun, which is the headquarters of the Forest Service.

This lack of trained botanists is to be deplored in view of the wide field that awaits investigation, a point that is clearly brought out by a map showing the large areas that are unexplored or only partially explored from the botanical point of view. In many areas the larger flowering plants have been well worked over, but it is particularly the smaller and more primitive forms of plant life that now need attention. The Indian Botanical Departments have hitherto surveyed mainly the higher forms of plant life ; but the primitive forms have an equally important significance to the plant geographer and the general botanist. Dr. Biswas touches on this latter point in his section dealing with mangrove swamps, which he divides into regions according to species and to their algal associations, which are said to be characteristic.

In the main body of his address he deals with the vegetation of the rain forest regions of Eastern India and Burma, enumerating the chief species that constitute the various strata in forest of this type. Later on he deals with the effect of altitude on plant growth and the characteristic species of the eastern Himalayas. He suggests that the Abor country of northern Assam might prove to be particularly suitable for the study of questions concerning the ecology and geographical distribution of plants.

A considerable portion of the address is occupied in a discussion of the different elements that comprise the Indian flora. He quotes Dr. Chatterjee's estimate that more than 61 per cent of the plants are endemic, and gives his own figure for the Sikkim Himalaya in the Darjeeling district alone as 50 per cent indigenous to the Himalaya, the rest being foreign species from other parts of Asia, America and Europe and a few from Australia. Many of these have no doubt been introduced either deliberately in cultivation or accidentally by trade routes, within comparatively recent times.

Dr. Biswas discusses the modern trend of systematic and taxonomical studies and traces the history of botanical study, stating that it received the attention of the Hindus more than 2,500 years ago. Plants were used by the ancient Rishis and sages in India in connexion with various rituals. Later on, plants were studied in relation to agriculture and horticulture, and medicinal plants receive particular attention in the Ayurveda. He thinks it not unlikely that the knowledge of plants spread gradually from Hindustan to Europe via Arabia, Syria and Greece. There is little doubt that botanical knowledge in Europe advanced through the herbalists. For example, 
d'Alechamps recognized eighteen classes of plants according to their medicinal properties. As knowledge inereased, the classification of plants took its proper form in the hands of De Candolle and Linnæus, and as a result of their work it has now reached its present high standard. It is still a matter of dispute as to the perfect system of classification and the best method of describing the plant. The idea, held until comparatively recently, that systematics consisted of a specialized and rather narrow branch of biology, empirical in character and without general application to other branches of science, is now recognized as out of date. Recent investigations of workers devoting their attention to morphology, ecology, anatomy, genetics, cytology and plant breeding can now be utilized correctly to stabilize the systematic position of a particular plant. In other words modern thought tends to the opinion that systematics must now be studied in relation to general biology.

As has already been mentioned, Dr. Biswas has covered a very wide field dealing with many different aspects. Possibly it would have been better if he had confined his discussions to a more limited field so as to bring home to the public his main point, which is the special need for more botanical research. No one can cavil at his plea for more development in this direction. India now has her destiny in her own hands. In the past most of the systematic work in botany was carried out by Europeans who have well and truly pointed the way, but now the "mantle of Elijah" has fallen on Dr. Biswas and his associates, and they are naturally anxious that progress should not be delayed.

The scope for systematic botany in India, as he has pointed out, is enormous. Many unknown or little-known plants await discovery, and many of them are doubtless of commercial, medicinal or agricultural importance. The part that systematic botany may well play in the economic side of development has been mentioned in the address, but might well have been reviewed even more fully as it plays an important part in deciding the actions of Governments. It has also proved its value during the present War when so many new products and so many substitutes have had to be found to cope with wartime shortages and demands. Let us hope that botany, and in particular systematics, will take a more leading part in the life of the Indian universities than apparently has been the case in the past, and also that private citizens may be found who will undertake work of this kind as a matter of choice. In Great Britain much work has been carried out by individuals in a private capacity. It has supplemented the organized work of the universities and the scientific departments of State, and has resulted in valuable accumulations of our knowledge of plants. This is a line of work that might with advantage be followed in India in the future.

\section{OBITUARIES}

\section{Prof. Warrington Yorke, F.R.S.}

As proof that any man of science enjoys fame extending beyond the limits of his own country, we have at our disposal one rather delicate test. The printed word has, of course, great value in this respect, and there is no doubt that publication of papers by foreign journals denotes a quite definite recognition of a man's status by his colleagues abroad. But it is when members of learned societies in other countries have become so interested in a man's work that they desire to see him in person, and hear him for themselves, that it may most truly be said that he has achieved an international reputation in his subject.

Warrington Yorke had attained that degree of eminence. This is evident from the number of his lecture engagements abroad, of which the following may be mentioned. In the year 1933 he lectured on chemotherapy to the members of the Medical Academy in Düsseldorf; in 1934, at the International Malaria Congress in Rome, he read a paper entitled "A Contribution to the Biological Side of Chemotherapy" ; in 1939, at the Third International Congress for Microbiology in New York, he gave an address on "Recent Work on the Chemotherapy of Protozoal Infections". During the same period he was also greatly in demand as a lecturer at home. $\mathrm{He}$ addressed the Medical Society for the Study of Venereal Disease on "Drug Resistance" in 1933, the Royal Society of Tropical Medicine and Hygiene on "Chemotherapy in Protozoal Infections" in the same year, and also in 1935; the Chemical Society of Liverpool on "Chemotherapy" in 1940, and the Biochemical Society of London on the "Diamidines" in 1941 .

A perusal of the above titles might lead the reader to suppose that Yorke had always specialized in the application of drugs to the treatment of disease, and certainly the high standing which he enjoyed as an exponent of chemotherapy would justify this supposition. But in fact his enthusiasm for this subject was a comparatively late development. It originated when, in 1929, he discovered a method by which the pathogenic trypanosomes which affect man and animals could be kept alive outside the animal body. This discovery placed in his hands a ready means by which he could study the effects of drugs on some of those protozoal parasites which cause disease in man. The fact that parasites treated with doses of certain drugs, insuffieient to kill them, might develop a remarkable resistance against the effects of further and larger doses of the same drugs, was of funda. mental importance in the drug therapy of such diseases as sleeping sickness. Of even greater biological significance, and of no less practical importance, 'was the discovery that such drug resistance, once acquired by the parasite, might persist even while the parasite was passing through its curious development in the vector. For example, an arsenic-fast strain of trypanosome would still possess its acquired arsenic-fast character even after the trypanosomes had completed their cycle in the body of the tsetse fly. But the discovery of the technical device mentioned would never in itself have enabled a man to advance his subject in such a notable manner as Yorke succeeded in doing. It was on account of the great knowledge and wide experience of tropical diseases he possessed, which he had acquired during many foregoing years of arduous work, that he found himself in a position to take the fullest advantage of this discovery.

Warrington Yorke was the son of the late Rev. H. Lefroy Yorke, and was born at Lancaster in 1883. He attended University School, Southport, and Epworth College, Rhyl, and was a student at the University of Liverpool, where he took his medical degree in 1905 . He went out to Nyasaland in 1907 